\title{
Same Game, Different Rules? Gender Differences in Political Participation
}

\author{
Hilde Coffé • Catherine Bolzendahl
}

Published online: 2 February 2010

(C) The Author(s) 2010. This article is published with open access at Springerlink.com

\begin{abstract}
We investigate gender gaps in political participation with 2004 ISSP data for 18 advanced Western democracies (N: 20,359) using linear and logistic regression models. Controlling for socio-economic characteristics and political attitudes reveals that women are more likely than men to have voted and engaged in 'private' activism, while men are more likely to have engaged in direct contact, collective types of actions and be (more active) members of political parties. Our analysis indicates that demographic and attitudinal characteristics influence participation differently among men and among women, as well as across types of participation. These results highlight the need to move toward a view of women engaging in differing types of participation and based on different characteristics.
\end{abstract}

Keywords Citizenship · Political participation · Activism . Gender. Cross-national

\section{Introduction}

Gender equality in political power and resources in industrialized democracies has grown tremendously in the

Hilde Coffé and Catherine Bolzendahl contributed equally to this work.

H. Coffé $(\bowtie)$

Department of Sociology/ICS, University of Utrecht,

Heidelberglaan 2,

3584 CS Utrecht, The Netherlands

e-mail: H.R.Coffe@uu.nl

C. Bolzendahl

Department of Sociology, University of California,

Irvine, CA, USA past fifty years. More women are running for and being elected to national parliaments than ever before, and a record number of women hold executive positions within their nations' government (Lovenduski 2005; Paxton et al. 2007), with a number of important consequences for political outcomes and priorities (Bolzendahl and Brooks 2007; Carroll 2001; Schwindt-Bayer 2006; Waring et al. 2000). Despite this success in influence and representation at the highest levels, research on a number of Western industrialized democracies also finds a persistent gender gap in citizens' political participation, with women less politically engaged than men (Burns 2007; Burns et al. 1997; Dalton 2008; Gallego 2007; Norris 2002; Paxton et al. 2007; Schlozman et al. 1999). Though some researchers, particularly when looking the U.S. or Great Britain, note the difference is often small in comparison to other cleavages such as education or age (Burns 2007; Norris 2002; Parry et al. 1992), gender is also a cleavage that cuts across these other areas of stratification making it salient for all citizens (Martin 2004; Risman 1998). Because political participation is a central component of democracy as well as a means for achieving greater equality, gender inequalities in political participation may both reflect and further reify gender stratification throughout society (Lister 2007; Verba et al. 1997; Young 2004).

We aim to re-evaluate findings regarding the gender gap participation with a new, more expansive approach. First, prior research has primarily focused on electoral, or what we refer to as "institutional" forms of participation such as voting, working on a campaign, and joining a party organization, because these are forms of participation inherent to the workings of the democratic government itself (Janoski 1998). Despite their systematic importance, prior work suggests these forms of political participation are declining or holding steady at lower levels. In comparison, among 
Western democracies participation is increasing in citizeninitiated and policy-oriented (here referred to as "activist") forms of political activity, emphasizing the increasing salience of broader approaches to participation (Dalton 2006, 2008; Norris 2002; Wattenberg 2002). The importance of such distinctions is heightened by the fact that all types of participation are not equal in the resources they require of participants or the meaning assigned to each type of engagement (Dalton 2008; Pattie et al. 2003). In particular, women's vibrant participation in informal political efforts and organizations (Bourque and Grossholtz 1998; Sarvasy and Siim 1994; Siim 2000) suggests non-formal engagement may be easier for women, as well as corresponding more strongly to their own definitions of (good) citizenship engagement (Harrison and Munn 2007), but a more nuanced approach to participation is missing from empirical research. Second, our focus allows us to build upon prior literature examining gendered pathways to participation. We do so by considering how and whether some characteristics matter more or differently for women or men when it comes to both institutionalized and activist types of participation, and across respondents from a broad range of industrialized democracies. While studies of political participation in the U.S. have made great strides in explaining how and why women and men participate differently, it is unclear the extent to which these can be generalized to other advanced Western democracies.

In sum, the purpose of our paper is to answer two related questions: First, is there a consistent gender gap in participation across all types of behavior? Second, do characteristics determining participation matter differently among men and among women? In formalizing these into hypotheses (in the following section), we build from prior work in Sex Roles (Bernstein 2005; Fridkin and Kenney 2007; Schreiber 2002; Schwarz et al. 1987; Stake 2007), that considers political participation as gendered behavior that may result from socialization, attitudes, and opportunities. We extend these approaches to note that gender differences may also result in different types of political engagement among men and women (for differing reasons), rather than simply a matter of more or less engagement, and to consider a broad international sample of 18 Western industrialized democracies: Austria, Flanders, France, Germany, Portugal, Spain, Switzerland, Denmark, Finland, the Netherlands, Norway, Sweden, Great Britain, Ireland, Australia, Canada, New Zealand, and the USA. As a partial control for cultural, historical and institutional influences, we limit our sample to affluent, culturally "Western" nations with a predominant history of Christianity, and relatively comparable historical experiences with democratic institutions and women's rights.

Using data from the 2004 International Social Survey Program (ISSP) module on citizenship, we measure voting and political party membership as "institutional" participation, and a variety of less institutionalized but nevertheless politically important behaviors, as "political activism," such as taking part in a demonstration, signing a petition, boycotting products for political, ethical or environmental reasons or contacting a politician. Our analysis supports theoretically differentiating between types of activism, by focusing separately on actions that are more private or collective in nature, and political actions that involve direct political contact (Pattie et al. 2003). Using linear and logistic regression models we examine the gender gap these forms of participation, as well as differences in the influence of socio-economic and politically relevant attitudinal characteristics among women and among men, finding that both types of participation and influences on levels of participation differ by gender.

\section{A Gender Gap in Participation}

A participatory public is crucial for democratic responsiveness and is seen as an intrinsic democratic good (Verba 1996), and thus systematic and persistent patterns of unequal participation along existing lines of stratification, such as gender, are threats to both political equality and democratic performance. While women have made substantial gains in wielding political influence, (Githens et al. 1994; Paxton et al. 2007; Waring et al. 2000), women are still found to participate less in formal politics across a variety of Western nations (Norris 2002; Parry et al. 1992; Schlozman et al. 1995, 1999; Verba et al. 1997). Differences in men's and women's political engagement, at least in the United States and Great Britain, are not as large as some other notable social group cleavages (e.g., racial or economic), but they are persistent (Burns 2007; Verba et al. 1997), and there is some evidence that these gaps exist similarly in democracies world-wide (Inglehart and Norris 2003; Norris 2002).

A number of factors have been suggested as explanations, namely that women are less likely to engage in politics because of their lower access to socio-economic resources. For example, men are far more likely to be employed full-time than women, and employment is positively related to political participation, information and efficacy among U.S. respondents (Schlozman et al. 1994, 1999). Thus controlling for employment status may mediate a substantial portion of a gender gap in participation. However, U.S. research suggests women's lower levels of political information, interest, and efficacy are important explanations for a gender gap independent of other characteristics (Verba et al. 1997). Women's lack of political resources such as political interest and information may be rooted in social processes such as gender socialization (Burns 2007; Lovenduski 2005; Rapoport 
1981; Verba et al. 1997). Women are socialized toward a gender role that is more passive, private, rule-abiding, and compassionate, while men are oriented toward leadership, public roles, autonomy and self-reliance (Brownmiller 1984; Fox and Lawless 2004; West and Zimmerman 1987). This socialization may contribute to women's lower levels of political engagement (Atkeson and Rapoport 2003; Rapoport 1981) with differences in political attitudes and participation beginning early in life (Fridkin and Kenney 2007; Hooghe and Stolle 2004) and continuing over the life course (Alwin et al. 1991).

\section{Political Participation: Beyond Voting and Campaigns}

A problem plaguing these findings however, is the tendency to conceptualize political engagement narrowly or to summarily combine different forms into a unidimensional scale. As scholars have argued (though rarely tested) perhaps women do not participate less, but rather, participate differently (Bourque and Grossholtz 1998; Harrison and Munn 2007; Lister 1998; Parry et al. 1992). Furthermore, even if the gender gap is persistent across types of participation, factors that mediate such a gap may not be. Those factors explaining a gender gap in participation in one area are not necessarily powerful in explaining the gender gap in other modes of participation (Armingeon 2007; Dalton 2006).

Though much of the previous research on political participation has focused on institutionalized forms such as voting in elections and political party activity, among industrialized nations, there is evidence that people are changing the ways in which they participate (Dalton 2006, 2008; Inglehart 1997). With citizens in industrialized democracies becoming more highly educated, technologically sophisticated, and policy and issue oriented, they are seeking out new ways of engaging with government and politics that reflect such skills and goals (Dalton et al. 2003).

Given such change, researchers have increasingly employed two strategies to understand political activity. First, they have broadened the scope of participation to include less "conventional" modes (Dalton 2006; Norris 2002), challenging the widely accepted assumption that citizens have become disengaged in politics, and underlining the need to incorporate less visible forms of engagement. Second, research suggests the importance of making theoretical distinctions in participation. Thus paying attention to types of participation as crucial for understanding systematic differences in the requirements they place on participants and in the nature of the actions (Verba et al. 1978). Especially from the framework of group differences, it is important to attend to distinctions in political participation that may shape a citizen's ability to engage and interest in engaging in a particular activity, as some researchers acknowledge (Dalton 2008; Norris and Curtis 2006; Pattie et al. 2003), though with little attention to gender cleavages.

\section{Women Boycott and Men Join Parties?}

The possibility that the measurement of participation itself explains any gender gap in participation has been argued by scholars in the theoretical field of gender and politics who claim that political participation research focuses too exclusively on formal organizations and voting (Goss 2003; Lister 2003; Orloff 1996). Scholars suggest men and women may be qualitatively different in patterns of and preferences for participation (Bourque and Grossholtz 1998; Burns 2007; Sarvasy and Siim 1994; Young 2004). Hooghe and Stolle (2004) find that 14-year-olds in the United States do not differ in anticipated levels of participation, but that girls favor more social-movement related forms, while boys prefer radical and confrontational actions.

As with gender differences in political participation in general, differences in the types of political participation men and women engage in may be ascribed to disparities in resources, political attitudes and gender roles. For example, women's lower average levels of socio-economic resources may make it more difficult for them to engage in timeintensive, expensive, or highly skilled forms of activity, such as campaigning for a candidate (Burns 2007; Lister 2003; Paxton et al. 2007). They may find it easier to participate in ways that can be incorporated in daily life and do not put more strain on already (relatively) limited resources, such as "private" types of actions (Stolle et al. 2005). And women's greater pressure to specialize in the "private" sphere may contribute to gender differences in participation with women participating in a less visibly and formally (Lister 2003; Lovenduski 1998; Risman 1998). Though not explicitly examining the participation gender gap among activist forms of participation, prior work based on American and European large scale surveys suggests men are more inclined to be involved in resource-dependent modes of activism (Dalton 2008; Gallego 2007; Norris 2002; Pattie et al. 2003). Distinguishing between activist and institutional forms of participation allows a better understanding of the true extent of such gaps. This is particularly important given that some cross-national research finds that gender differences in institutional forms of participation are less pronounced (Norris 2002; Parry et al. 1992) or absent altogether (Dalton 2008; Gallego 2007). However, little of this work has considered a broad sample of nations and simultaneously examined more activist types of participation. If some recent claims are correct (Dalton 2006, 2008), these activist forms of 
participation may be becoming increasingly important, and thus crucial to investigate for inequalities.

Before turning to theoretical insights that will be used to answer our second research question, we provide an overview of the expectations regarding a gender gap across different types of participation.

- Hypothesis 1: Men will be more likely to be members of a political party than women.

- Hypothesis 2: Women will be as likely as men to vote in elections.

- Hypothesis 3: Women will be more likely to be involved in private types of political activism in comparison to men.

- Hypothesis 4: Men will be more likely to be involved in collective types of action than women.

- Hypothesis 5: Men will be more likely to be involved in more direct contact forms of activities such as contacting politicians or media, or joining an internet political forum.

\section{Different Paths to Participation}

In addition to their affect on gender gaps in the amount of participation across different modes, it is possible that demographic and attitudinal characteristics may determine participation differently among men and among women. Research tends to assume socio-economic and political resources to matter similarly in determining women's and men's participation, thus similar levels of resources will lead to similar levels of participation. However, the processes that contribute to the creation of "gender" (i.e., differing meanings assigned to men and women's position in society and exposure to socialization pressures) suggests the same characteristics may produce different outcomes (Risman 1998; West and Zimmerman 1987).

With some notable exceptions looking at specific explanatory factors (e.g. in the U.S., inequalities at home (Burns et al. 1997) and workplace factors (Schlozman et al. 1999)) little empirical research has investigated gender differences in the link between political participation and socio-economic characteristics and political attitudes. For example, while many studies indicate that men's higher average levels of political interest, efficacy and trust matter explain a portion of the gender gap in participation (Abramson 1983; Banducci et al. 1999; Chanley et al. 2000; Verba et al. 1997), research has not tested whether these attitudes matter differently among men and among women. Even less research has investigated gender differences in the effect of background and attitudinal characteristics on different types of political activity. It may indeed be that for example having children has a more negative effect for women than for men, but that this gender difference is only evident for time demanding activities such as demonstrating. However, extrapolating from research on the gender gap in participation - the majority on U.S. samples we can anticipate differences in effects among men and among women and formulate some hypotheses for participation in general for some socio-economic characteristics. Specifically, being in a professional occupation generally increases political participation (Verba et al. 1995), but may matter more in differentiating participation among women because attaining a professional occupation is rarer and more difficult for women than men.

U.S. research also indicates employment is the outcome of different opportunities and accumulated advantages for men (Schlozman et al. 1999), and cross-nationally it is clear that women in industrialized democracies spend more time on housework than their male partners even when both partners work full time (Batalova and Cohen 2002; Knudsen and Waerness 2008). Thus, being employed may have a negative effect on women's participation due to accumulated indirect disadvantages and a direct lack of leisure time that may not affect men's participation as strongly. Along these lines, Schlozman et al. (1999) find that women's political participation declines with hours on the job, but not men's.

By contrast, religiosity and religious affiliation may matter more for men than for women. Research shows that religiosity and religious affiliation can have a positive impact on participation by teaching civic skills (Putnam 2000). On average, women are more likely to be religious and religiously affiliated, and thus if men are religious, it is likely to matter more. Generally speaking, if men or women differ from the average profile of their gender group on a characteristic, that characteristic is likely to be more influential. In U.S. research, studies have found that church or mosque attendance has a stronger positive effect on men's political engagement (Read 2007; Robnett and Bany 2009).

Marriage and parenthood are anticipated to have a stronger negative effect among women than among men, where marriage may even boost participation (Rotolo 2000). Once married, women's leisure time declines to a greater extent than men's, and women tend to increase the amount of time spent on housework, whereas men's contribution decreases (Gupta 1999; Sayer 2005). Thus, marriage might lower political participation among women and boost it among men (Rotolo 2000). This is expected to be particularly the case for resource-demanding activities such as collective types of actions, which expect participants to be at a certain place at a certain time (regardless of financial, familial, or time limitations). As with marriage, Dutch findings indicate divorce changes the resources that people have, and the effect is generally stronger and more negative for women (Poortman 2000). Hence, the effect of separation may be more negative for women then for men. As for marriage, we 
anticipate these gender differences to occur particularly for time-demanding activities which are not easily incorporated into daily life.

In sum, based on theoretical insights and/or previous research we are able to develop a number of expectations for the effects of certain socio-economic characteristics differing among women and among men:

- Hypothesis 6: A high status occupation is expected to have a stronger positive effect among women than among men.

- Hypothesis 7: Church attendance will matter more for increasing men's participation than for women's.

- Hypothesis 8: Being employed will have a stronger positive effect among men than among women.

- Hypothesis 9: Being married, having children and being divorced are anticipated to have a negative effect for women and a positive effect for men.

\section{Method}

We utilize data from the 2004 International Social Survey Program (ISSP) module on Citizenship. The ISSP is a cross-national collaboration of standardized surveys, each of which is fielded by a scientific organization within the member nation, typically as part of a larger random survey of the adult non-institutionalized population (ISSP 2004). More detailed information is available in the study report (Scholz et al. 2008). We look at 18 Western industrialized countries: Austria, Flanders, France, Germany, Portugal, Spain, Switzerland, Denmark, Finland, the Netherlands, Norway, Sweden, Great Britain, Ireland, Australia, Canada, New Zealand and the USA. Listwise deletion of observations with missing data on the independent variables was used (Allison 2002). Prior to dropping missing values the sample size is 25,263 . The final sample size is 20,359 for all models except voting, which is 16,564. A question on voting behavior was not asked in Flanders, and we exclude Australia from the analysis on voting because it is mandatory. However, results are the same if Australia is included. We analyze voting as a separate sample due to these issues and a higher proportion of missing values for this variable $(12 \%)$. Before turning to the analyses, in the next sections we discuss the dependent and independent variables. Descriptive statistics are available in Table 1.

Dependent Variables: Institutionalized Participation and Political Activism

To assess political engagement broadly we use ISSP items asking respondents if they have done a variety of forms of political actions. Formal, more traditional electoral participation is measured according to whether the respondent is a member of a political party and whether the respondent voted in the last election. For party membership possible responses include: (1) belong and participate (4\%); (2) belong and do not participate (8\%); (3) used to belong (8\%); and (4) never belonged (80\%). The item was reverse coded such that higher values refer to more engagement and to start at zero. Voting activity is measured by a yes/no dummy variable, and $84 \%$ of respondents said they voted in the last election

In addition to these two institutional forms of political participation, we analyze political activism through eight measures of less conventional political action. In doing so, we followed prior research suggesting these types of participation may be organized according to theoretical categories. While the items scale reasonably well as one aggregate measure, the patterns previously found in Great Britain by Pattie et al. (2003) using the 2000 British Citizen Audit were supported in confirmatory factor analyses. Specifically, our results mirror those of Pattie et al. (2003) in theoretically grouping actions which are more private in nature and involvement; actions involving a public, or group-oriented activity; and actions in direct political contact, or the effort to project an individual opinion to a wider group or higher authority (factors scores available upon request).

Thus, private political action is based on items asking the respondent whether in the past year they have signed a petition; boycotted, or deliberately bought, certain items for political, ethical or environmental reasons; or donated money or raised funds for a social or political activity $(\alpha=.61)$. A scale of collective political action uses items asking whether the respondents took part in a demonstration or attended a political meeting or rally $(\alpha=.61)$. Finally, political contact actions are measured as whether the respondent has contacted a politician, contacted the media or joined an internet political forum $(\alpha=.66)$. For the three item scales, respondents missing on two or more items were deleted, and for the two item scale, only when missing on both items. Results using listwise deletion of all missing values are consistent with this approach. Scales were divided by the total number of valid responses, thus range from zero to three. The scales are coded such that higher values indicate more engagement. The alpha scores are not remarkable high, but are within the acceptable range for large-scale survey analysis, and are supported by factor scores and results from analyzing each item separately.

\section{Independent Variables}

The main focus of the analysis, gender, is a dichotomous variable with the value 0 for male and 1 for female 
Table 1 Means/proportions for all variables (standard deviations in parentheses) across 18 industrialized democracies.
International Social Survey

Program, 2004

${ }^{\text {a }}$ Voting measure is missing Flanders and excludes Australia

${ }^{\mathrm{b}}$ Significance tests conducted through regressions with country fixed effects and robust standard errors clustered by nation

$* p<.05$

\begin{tabular}{|c|c|c|c|c|}
\hline & Range & Men & Women & Sig. test ${ }^{\mathrm{b}}$ \\
\hline \multicolumn{5}{|l|}{ Dependent variables } \\
\hline Political party membership & $0-3$ & $.40(.82)$ & $.30(.73)$ & $*$ \\
\hline Voted in last election $^{\mathrm{a}}$ & $0 / 1$ & $.84(.37)$ & $.83(.37)$ & n.s. \\
\hline Private political activism scale & $0-3$ & $1.57(.81)$ & $1.67(.83)$ & $*$ \\
\hline Signed a petition & $0-3$ & $1.83(.97)$ & $1.90(.99)$ & $*$ \\
\hline Boycott/bought items $[\ldots]$ & $0-3$ & $1.40(1.10)$ & $1.50(1.14)$ & $*$ \\
\hline Donate/raise funds $[\ldots]$ & $0-3$ & $1.49(1.15)$ & $1.60(1.16)$ & * \\
\hline Collective political activism scale & $0-3$ & $1.11(.82)$ & $.99(.80)$ & * \\
\hline Demonstrated & $0-3$ & $1.07(.95)$ & $1.00(.94)$ & * \\
\hline Attended a political mtg./ rally & $0-3$ & $1.15(.97)$ & $.98(.93)$ & $*$ \\
\hline Political direct contact activism scale & $0-3$ & $.84(.66)$ & $.69(.61)$ & * \\
\hline Contacted politician & $0-3$ & $1.15(.95)$ & $1.01(.92)$ & * \\
\hline Contacted media & $0-3$ & $.85(.86)$ & $.67(.79)$ & * \\
\hline Joined internet forum & $0-3$ & $.50(.73)$ & $.37(.63)$ & * \\
\hline \multicolumn{5}{|l|}{ Independent variables } \\
\hline Trust in government & $0-4$ & $1.93(1.02)$ & $1.85(1.00)$ & * \\
\hline Political efficacy & $0-8$ & $3.38(2.22)$ & $3.22(2.17)$ & * \\
\hline Political interest & $0-3$ & $1.66(.83)$ & $1.44(.82)$ & * \\
\hline \multicolumn{5}{|l|}{ Education (ref: less than degree) } \\
\hline University degree & $0 / 1$ & $.18(.39)$ & $.17(.37)$ & n.s. \\
\hline Age & $15-97$ & $48.13(16.57)$ & $47.08(16.69)$ & n.s. \\
\hline \multicolumn{5}{|l|}{ Employment status (ref: not in 1.f.) } \\
\hline Full time employment & $0 / 1$ & $.61(.49)$ & $.36(.48)$ & * \\
\hline Part-time employment & $0 / 1$ & $.05(.22)$ & $.19(.39)$ & $*$ \\
\hline \multicolumn{5}{|l|}{ Spouse employment (ref: nilf, no spouse) } \\
\hline Full time employment & $0 / 1$ & $.26(.44)$ & $.44(.50)$ & $*$ \\
\hline Part-time employment & $0 / 1$ & $.15(.35)$ & $.03(.16)$ & $*$ \\
\hline \multicolumn{5}{|l|}{ Occupation (ref: nilf/no occupation) } \\
\hline Professionals and managers & $0 / 1$ & $.28(.45)$ & $.21(.41)$ & * \\
\hline Technicians and associate professionals & $0 / 1$ & $.14(.35)$ & $.16(.36)$ & n.s. \\
\hline Service workers and clerks & $0 / 1$ & $.12(.32)$ & $.33(.47)$ & $*$ \\
\hline Skilled agriculture and craft workers & $0 / 1$ & $.33(.47)$ & $.09(.29)$ & * \\
\hline Elementary low-skill occupations & $0 / 1$ & $.06(.25)$ & $.08(.26)$ & n.s. \\
\hline \multicolumn{5}{|l|}{ Marital status (ref: never married) } \\
\hline Married, living together or widowed & $0 / 1$ & $.67(.47)$ & $.68(.47)$ & n.s. \\
\hline Divorced or separated & $0 / 1$ & $.08(.26)$ & $.11(.31)$ & * \\
\hline \multicolumn{5}{|l|}{ Household composition (ref: adult $\mathrm{HH}$ ) } \\
\hline With children & $0 / 1$ & $.31(.46)$ & $.36(.48)$ & * \\
\hline \multicolumn{5}{|l|}{ Place of residence (ref: rural) } \\
\hline Urban & $0 / 1$ & $.26(.44)$ & $.26(.44)$ & n.s. \\
\hline \multicolumn{5}{|l|}{ Religious denomination (ref: no affil.) } \\
\hline Roman Catholic & $0 / 1$ & $.37(.48)$ & $.40(.49)$ & $*$ \\
\hline Protestant & $0 / 1$ & $.32(.47)$ & $.35(.48)$ & $*$ \\
\hline Other religion & $0 / 1$ & $.06(.23)$ & $.06(.24)$ & n.s. \\
\hline Religious attendance & $0-7$ & $2.05(2.16)$ & $2.54(2.26)$ & $*$ \\
\hline Observations & 20,359 & 9,895 & 10,464 & \\
\hline
\end{tabular}


respondents. Further, education is measured as a dichotomous variable indicating whether the individual has attained a university degree. Age is a continuous control variable. We also introduce a squared value for age to control for non-linearities in the effect as a life-course control.

Employment status is represented by three categories: full time employment, part-time employment and not employed. Next to the respondents' employment, we also introduce the spouse's employment, coding similarly to respondent's employment status. Occupation has been operationalized on the basis of the 1988 International Standard Classification of Occupation (ISCO) and distinguishes six groups: managers and professionals; technicians and associate professionals; clerks, service workers, shop and market sales workers, and armed forces; skilled agriculture workers, craft workers, and plant and machine operators and assemblers; elementary occupations; no occupation. Very high numbers of missing values on income made it impossible to include. However, occupation may be a more useful concept overall given that it taps into differential earnings groups, and latent aspects of social class (Abbott 1993).

Marital status has three categories: respondents who are married, are living together as married, or who are widowed; respondents who are divorced or separated; respondents who are single and have never been married. Household composition is a dichotomous variable distinguishing households with children from other household compositions. More nuanced measures of household composition, which divided household according to single adult with children households, all adult households, and two or more adults with children households were also operationalized. None were significant, thus a more parsimonious measure was chosen. The place of residence is self-assessed and coded as 0 for rural and 1 for urban. Religious denomination is divided in four categories: no religious denomination; Roman Catholic; Protestant; other religion. Religious attendance is a continuous variable ranging from (0) never to (7) several time a week.).

A variety of politically-relevant attitudes may also be important. In particular, we look at three types of political attitudes: trust in government, political efficacy, and political interest. Explaining political action by political attitudes may face problems of reverse causality. Due to this we refrain from statements about the causality of the effects and talk instead about correlation. Our indicator of trust in government is agreement on a Likert-type scale from 1 to 5 that "most of the time we can trust people in government to do what is right." This single general measurement of political trust is considered to be the most appropriate for tapping citizens' basic evaluative orientation (Ulbig 2002). The measure of political efficacy is agreement with two items scaled: “people like me don't have any say about what the government does," and "I don't think the government cares much what people like me think." These items are similar to those included in the American National Election Studies (Dyck and Lascher 2009). Each item was assessed on a Likert-type scale ranging from (1) "strongly agree" to (5) "strongly disagree." One question is used to measure political interest: "How interested would you say you personally are in politics?", a common approach in the social science research since the 1950s (Gabriel and van Deth 1995; Hadjar and Schlapbach 2009). The possible answers range from (1) "Very interested" to (4) "Not at all interested." All answers have been reversed so that higher values refer to more efficacy, trust or interest, and recoded to start at zero.

Finally, we control for context, broadly defined, by including dummy variables for each country. A gender gap in citizenship norms may be shaped by contextual factors beyond the scope of this analyses, thus it is important to account for possible macro influences since they may influence political activism (Lister et al. 2007). Since our focus is not on explaining cross-national differences we exclude these coefficients from our tables presented below. All statistics were run with the statistical program Stata version 10.1 .

\section{Results}

\section{Descriptive Statistics: Bivariate Gender Differences}

Before turning to our explanatory multivariate analyses, we present means/proportions, standard deviations, and significance test results for gender differences for all dependent and independent variables in Table 1 . Gender differences are tested through appropriate (mainly logistic) bivariate regression models that include dummies for country as well as robust standard errors clustered by nation to test for significant gender differences.

Looking at the dependent variables, there is no evidence of a gender gap in participation in voting, but women are less likely than men to be active political party members. Turning to the political activism, we find significant gender differences, with women significantly less engaged than men for all measures but for the private activism in which women are significantly more likely to engage than men. Our results suggest that a gender gap in political participation should not be generalized toward the entire spectrum of political engagement. Results for electoral participation suggest that gender equality in politics in formal politics has been most successful. Yet, women intend to engage less in collective types of political action, as would be predicted based on women's lower time and resource availability, and socialization in more private roles. 
However, all gender differences may disappear when controlling for gender differences in resources that facilitate political activity. Just looking at the descriptive statistics, we see that across many of the demographic controls, men and women are significantly different, and differences are in accordance with previous literature. Notably, women have fewer economic resources than, which we would expect to depress women's participation. Whereas $61 \%$ of the men are employed full-time and $28 \%$ have a professional occupational position, compared to respectively $36 \%$ and $21 \%$ of women. Moreover, women have greater potential burdens on resources. For example women are more likely to be divorced/separated than men $(11 \%$ compared to $8 \%$ ) and to live with children (36\% compared to $31 \%$ ). Among the political attitudes, we also observe distinct differences between men and women. Women, on average, feel significantly less politically efficacious and have substantially less trust in government and interest in politics than men.

\section{Multivariate Analyses: Gender Gaps in Political Participation}

\section{Institutional Participation: Voting and Political Party Membership}

At the bivariate level we found women were less likely to be involved in political parties but found no difference in electoral participation. However, after controlling for socioeconomic characteristics and political attitudes in Table 2, a gender gap emerges. The results presented in Table 2 are based on logistic models: ordered logistic models for party membership and binary logistic models for voting. Due to the skewed nature of the political party membership variable, wherein most respondents report having never belonged to a party, we also ran binary logistic models on a dichotomous measure of " never belonged" versus all else. The results were the substantively the same as those we report for ordered logistic models.

Because logistic coefficients do not convey the substantive size of an estimated coefficient we report z-scores rather than standard errors, and interpret main findings with odds ratios $\left(\mathrm{OR}=\mathrm{e}^{\mathrm{b}}\right)$ (Long 1997). Odds ratios below 1 indicate that the covariate is associated with lower levels of participation, and odds ratios above one indicate a positive association with participation. For example, an odds-ratio of 1 for women in the voting model would indicate that the odds of having voted are about the same for both men and women. Two models are presented for both dependent variables (as well as for the dependent variables that follow below). The first models investigate to what extent a possible gender gap may be explained by gender differences in socio-economic resources. The second models investigate the relevance of gender differences in both socio-economic characteristics and in attitudes towards politics. Thus, the first models control for demographic influences, while the second also controls for relevant political attitudes. Multicollinearity was explored by investigating the variance inflation factors (VIF) for all independent variables in each model. No problematic collinearity was discovered.

For tests of significant differences across models we use a Chow test for all linear regression models (e.g., our activism outcomes) by running models as seemingly unrelated regressions and testing resultant coefficients. Due to the probabilistic nature of logistic regressions and the fact that differences in the estimated coefficients tell us nothing about the differences in the underlying impact of a variable (x) on two groups, we establish significant differences by examining differences in the odds ratios and changes in the predicted probabilities for a given coefficient across all levels of the outcome variable (Allison 1999; Long and Freese 2006). Where differences are found to be significant and/or substantive, this evidence for such a conclusion is discussed in the text below.

Due to space and given our focus on the gender difference, we exclude the socio-demographic independent variables from presentation in Table 2, though they are included in the model.

First, we examine membership in political parties and find that controlling for socio-demographic characteristics, women's odds of participation in political parties are 32.8\% less than men's $(\mathrm{OR}=.67)$. This finding mirrors the bivariate result and is in line with our expectation (Hypothesis 1). Both political efficacy $(\mathrm{OR}=1.05)$ and interest $(O R=2.39)$ are significantly related to party membership, and controlling for political attitudes substantively mediates the gender gap, with women's odds of participation now only $21 \%$ less than men's. Examining changes in predicted probabilities for all levels of party involvement shows that controlling for political attitudes cuts the gender effect in half, though confidence intervals around the predicted probabilities for some levels of party membership overlap across models (Allison 1999; Long 2007).

Next we turn to electoral participation and find in accordance with Hypothesis 2 men and women are equally likely to have voted in the last election. It is only after turning to a model that includes political attitudes that a gender gap emerges, indicating women are more likely to have voted. The confidence intervals around predicted probabilities of voting for women in the based model and model including attitudes do not overlap further suggesting a significant change (Long 2007).Women are, on average, less likely to feel politically efficacious and interested than men, and once the strong positive relationship of these 
Table 2 Logistic regression results for the gender gap in political party membership, voting behavior, and OLS results for private, collective, and direct political contact activism across 18 industrialized democracies.

\begin{tabular}{|c|c|c|c|c|c|c|c|c|c|c|}
\hline \multirow{2}{*}{ Gender Gap } & \multicolumn{2}{|c|}{$\begin{array}{c}\text { Party } \\
\text { Membership } \\
\beta(\mathrm{z}) \\
\end{array}$} & \multicolumn{2}{|c|}{$\begin{array}{c}\begin{array}{c}\text { Voted in } \\
\text { Last Election }^{\mathrm{a}}\end{array} \\
\beta(\mathrm{z}) \\
\end{array}$} & \multicolumn{2}{|c|}{$\begin{array}{c}\begin{array}{c}\text { Private } \\
\text { Activism }\end{array} \\
\beta \text { (s.e.) }\end{array}$} & \multicolumn{2}{|c|}{$\begin{array}{c}\text { Collective } \\
\text { Activism } \\
\beta \text { (s.e.) }\end{array}$} & \multicolumn{2}{|c|}{$\begin{array}{c}\text { Political } \\
\text { Contact Activism } \\
\beta(\text { s.e. }) \\
\end{array}$} \\
\hline & & & & & & & & & & \\
\hline Female & $\begin{array}{c}-.40 * * \\
(4.99)\end{array}$ & $\begin{array}{c}-.24^{* *} \\
(3.55)\end{array}$ & $\begin{array}{c}-.03 \\
(-.47)\end{array}$ & $\begin{array}{c}.14 * \\
(2.68)\end{array}$ & $\begin{array}{l}.06^{*} \\
(.02)\end{array}$ & $\begin{array}{l}.12 * * \\
(.02)\end{array}$ & $\begin{array}{l}-.14 * * \\
(.03)\end{array}$ & $\begin{array}{l}-.06^{*} \\
(.02)\end{array}$ & $\begin{array}{l}-.18 * * \\
(.01)\end{array}$ & $\begin{array}{l}-.12 * * \\
(.01)\end{array}$ \\
\hline \multicolumn{11}{|l|}{ Political Attitudes } \\
\hline Trust in Government & - & $\begin{array}{c}.00 \\
.(19)\end{array}$ & - & $\begin{array}{c}.03 \\
(1.02)\end{array}$ & - & $\begin{array}{l}-.04 * * \\
(.01)\end{array}$ & - & $\begin{array}{l}-.02 * * \\
(.01)\end{array}$ & - & $\begin{array}{l}-.03 * * \\
(.00)\end{array}$ \\
\hline Political Efficacy & - & $\begin{array}{c}.05^{* *} \\
(3.21)\end{array}$ & - & $\begin{array}{c}.12^{* * *} \\
(7.32)\end{array}$ & - & $\begin{array}{l}.04 * * \\
(.00)\end{array}$ & - & $\begin{array}{l}.03 * * \\
(.00)\end{array}$ & - & $\begin{array}{l}.03 * * \\
(.00)\end{array}$ \\
\hline Political Interest & - & $\begin{array}{c}.87 * * \\
(22.58)\end{array}$ & - & $\begin{array}{c}.66^{* * *} \\
(24.70)\end{array}$ & - & $\begin{array}{l}.23 * * \\
(.01)\end{array}$ & - & $\begin{array}{l}.31 \text { ** } \\
(.01)\end{array}$ & - & $\begin{array}{l}.24 * * \\
(.02)\end{array}$ \\
\hline Constant/Cut 1 & $\begin{array}{l}2.24 \\
(.32)\end{array}$ & $\begin{array}{c}4.61 \\
(.36)\end{array}$ & $\begin{array}{c}-4.01 \\
(-10.95)\end{array}$ & $\begin{array}{c}-5.62 \\
(13.41)\end{array}$ & $\begin{array}{l}1.26 \\
(.08)\end{array}$ & $\begin{array}{l}.69 \\
(.08)\end{array}$ & $\begin{array}{c}.79 \\
(.06)\end{array}$ & $\begin{array}{l}.00 \\
(.08)\end{array}$ & $\begin{array}{c}.75 \\
(.06)\end{array}$ & $\begin{array}{l}.15 \\
(.08)\end{array}$ \\
\hline Cut 2 & $\begin{array}{l}2.94 \\
(.37)\end{array}$ & $\begin{array}{l}5.36 \\
(.41)\end{array}$ & - & - & - & - & - & - & - & - \\
\hline Cut 3 & $\begin{array}{l}4.34 \\
(.38)\end{array}$ & $\begin{array}{l}6.82 \\
(.42)\end{array}$ & - & - & - & - & - & - & - & - \\
\hline $\mathrm{R}$-squared & .08 & .13 & .18 & .22 & .20 & .26 & .12 & .22 & .12 & .22 \\
\hline Observations & 20,359 & 20,359 & 16,564 & 16,564 & 20,359 & 20,359 & 20,359 & 20,359 & 20,359 & 20,359 \\
\hline
\end{tabular}

Robust z-statistics and standard errors in parentheses

International Survey Program, 2004

Shaded cells indicate coefficients are significantly $(p<.05)$ different from model without attitudinal controls. OLS models tested at $p<.05$ using Chow tests. Logistic tests are based on odds ratios and changes in the predicted probabilities for a given coefficient across all levels of the outcome variable. All models control for education, age, age-squared, marital status, employment status, spouse's employment status, occupation, children in household, church attendance, religious denomination, and country fixed effects

${ }^{a}$ Voting models are missing Flanders and exclude Australia

$* p<.05, * * p<.01$

attitudes with voting is controlled for, it appears that women otherwise have a greater probability of voting $(\mathrm{OR}=1.14)$.

\section{Political Activism: Private, Collective and Contact Actions}

Initial results indicated that a bivariate gender gap exists with respect to political activism, though in the case of private types of action this gap favors women. Table 2 presents the results of multivariate OLS regressions, which were supported by logistic regressions of the individual items (results available upon request).

The base model for private types of action (e.g., boycotting goods, signing petitions), indicates that demographic differences between men and women cannot fully explain the gender gap and women are still more likely to engage in these activities, confirming Hypothesis 3. Moving onto a model that controls for political attitudes significantly strengthens the gender relationship. While trust in government is negatively related to private activism, there are positive effects from political efficacy and interest. In comparison, and even controlling for socio-economic characteristics, women are still significantly less likely than men to engage in collectivistic types of actions (e.g., attending a rally or demonstration). This negative relationship is significantly weaker when controlling for political attitudes but remains significant as we had expected (Hypothesis 4). Finally, results for models of direct contact types of actions (e.g., writing a letter to a politician or newspaper), also suggest-as we had anticipated in Hypothesis 5-women are less participatory despite controls for socio-economic characteristics and political attitudes. However, the negative relationship between gender and contact actions is significantly weaker once attitudes are included.

In sum, models for mainstream political participation and less conventional political activism suggest evidence of a gender gap in participation, however, not always 
indicating women participate less. For voting, initial null results hid gender differences. Once demographic and attitudinal cleavages are controlled for, women are more likely to vote. By contrast, women are less likely to belong to a political party, before and after controlling for sociodemographic and attitudinal characteristics. For political activism, we found that in the case of private activism controlling for other factors strengthened the gender effect (i.e., women's greater participation), and otherwise it decreased males' greater likelihood of engagement, especially in the case of collective types of action.

\section{Influences on Participation Among Women and Among Men}

Moving onto our second research question, we now consider the extent to which socio-economic and attitudinal characteristics shape participation differently among women and among men by presenting separate models for males and females. Intrinsic in these models is the idea that characteristics relating to political participation might matter differently for men and women. Results for models of our institutional forms of participation are in Table 3.

Models for political party involvement show few differences in effects across the gender groups with a couple notable exceptions. Although full and part time employment does not significantly increase participation among women or among men, the sizes of the effects are substantially different across models. In line with Hypothesis 8 presented above, we find that the effect of employment is stronger for men (Schlozman et al. 1999). Based on the results from predicted probabilities based on this model, men's probability of belonging to or being active in parties is about $10 \%$ if they are full or part time employed (all other variables at their mean), while women's is roughly $6 \%$ (all other variables at their mean). Also in line with Hypothesis 9, whereas having children in the household has a modest negative effect across models, the effect is stronger for women than for men. Women have only a $6 \%$ predicted probability of belonging to or being active in a political party, while men with children in the house have over an $8 \%$ predicted probability. However, it remains interesting that among women, holding a university degree significantly increases the likelihood of political party involvement, while this is insignificant for men.

Models of voting behavior indicate some cross-gender differences as well. Political interest matters especially for women at high levels of interest, where the effect increases women's predicted probability have having voted much more than men's. At low levels of interest the effect on voting is similar across men and women. Age has a positive effect among men and women, but calculating predicted probabilities across the age range reveals this effect differs substantially for women and men. At younger ages (e.g., 25), men have much higher predicted probabilities of voting. In early middle age (e.g., 45) men and women have similar probabilities of having voted, but above age 50 women are more likely to have voted than men. As for party membership, among women, having a university degree significantly increases the likelihood of voting, but not among men. For men, any amount of employment increases voting, but among women it is only being employed full-time that matters. Confirming Hypothesis 9, our results indicate that divorced men are not less likely to vote than single men, whereas being divorced significantly decreases women's likelihood to cast a vote. Such findings highlight the importance of considering gendered participation patterns.

Table 4 presents gender-specific models for participation in individualistic, collective, and direct contact forms of activism.

As we saw in Table 2, controlling for socio-economic characteristics did not fully mediate a gender gap in collective action and political contact. However, if women had the same high levels of political interest and efficacy as men, women's greater participation in private activism would be even higher than men's, and the gap in other types of activism would shrink significantly. Yet, the gender specific models in Table 4 suggest political attitudes rarely matter differently in encouraging or discouraging participation among women and among men. Only for private activism, where women already outperform men, do attitudes matter differently, with women having a stronger relationship between political efficacy and private activism than men. As with Table 3, it is demographic characteristics that are more decisive.

For both private and collective activism, married women are less participatory than single women, while married men do not differ significantly from single men, confirming Hypothesis 9. Divorced men tend to be more participatory in private activism than single men, whereas being divorced or separated does not affect women's engagement in private types of activism. Engaging in direct political contact presents contrary findings. Being married significantly decreases men's participation in political contact, but does not influence women's level of political contact. Yet, being divorced is linked to increases in women's involvement in political contact but does not so for men. Such contradictory findings highlight once more the necessity of thinking about modes of participation quite differently.

In line with Hypothesis 8, for men, being employed parttime increases participation in all three areas, while it only slightly increases women's level of private activism. So, as with the more institutional types of participation, part-time employment seems to matter more positively for men than 
Table 3 Logistic regression results for demographic and attitudinal predictors of political party membership and voting behavior among women and among men across 18 industrialized democracies.

\begin{tabular}{|c|c|c|c|c|c|c|c|c|}
\hline & \multicolumn{4}{|c|}{ Party Membership } & \multicolumn{4}{|c|}{ Voting $^{a}$} \\
\hline & \multicolumn{2}{|c|}{ Women } & \multicolumn{2}{|c|}{ Men } & \multicolumn{2}{|c|}{ Women } & \multicolumn{2}{|c|}{ Men } \\
\hline & $B$ & $(z)$ & $\beta$ & (z) & $B$ & $(z)$ & $B$ & (z) \\
\hline \multicolumn{9}{|l|}{ Political Attitudes } \\
\hline Trust in Govt. & -.01 & $(-.42)$ & .02 & (.43) & .02 & $(.59)$ & .03 & $(1.25)$ \\
\hline Political Efficacy & $.04 *$ & $(2.45)$ & $.06 * *$ & $(2.60)$ & $.11^{* *}$ & $(4.16)$ & $.12 * *$ & (9.69) \\
\hline Political Interest & $.89 * *$ & (15.68) & $.84 * *$ & (19.61) & $.74 * *$ & $(20.40)$ & $.56^{* *}$ & (13.85) \\
\hline \multicolumn{9}{|l|}{ Controls } \\
\hline University Deg. & $.25^{*}$ & $(2.23)$ & .14 & (1.16) & $.31 * *$ & $(2.55)$ & .10 & $(.55)$ \\
\hline Age & $.04 * *$ & $(2.63)$ & $.06 * *$ & $(3.64)$ & $.16^{* *}$ & (10.09) & $.09 * *$ & $(5.13)$ \\
\hline Age-squared & -.00 & $(-1.27)$ & $-.00 *$ & $(-2.14)$ & $-.00 * *$ & $(-8.44)$ & $-.00 *$ & $(-2.55)$ \\
\hline Married/Widow & .07 & $(.58)$ & .15 & $(1.87)$ & .14 & $(.97)$ & .19 & $(1.51)$ \\
\hline Div./Sep. & .24 & $(1.84)$ & $.25^{*}$ & $(2.46)$ & $-.45 * *$ & $(-3.36)$ & -.20 & $(-1.29)$ \\
\hline Employed F-T & .01 & $(.12)$ & .13 & $(1.57)$ & $.17 *$ & $(1.82)$ & $.36 * *$ & $(2.95)$ \\
\hline Employed P-T & .02 & (.16) & .25 & (1.90) & .20 & $(1.32)$ & $.35^{* *}$ & $(3.27)$ \\
\hline Spouse Emp. F-T & .07 & $(.76)$ & .02 & $(.24)$ & .15 & $(1.65)$ & $.29 * *$ & $(3.47)$ \\
\hline Spouse Emp. P-T & -.02 & $(-.09)$ & -.04 & $(-.31)$ & .07 & $(.30)$ & .17 & (1.19) \\
\hline Professional Occ. & .11 & $(.45)$ & -.03 & $(-.32)$ & .39 & $(2.12)$ & -.06 & $(-.27)$ \\
\hline Technical Occ. & -.02 & $(-.11)$ & -.02 & $(-.22)$ & $.48 * *$ & $(3.38)$ & .09 & (.453) \\
\hline Service Occ. & .02 & $(.10)$ & -.09 & $(-.80)$ & $.29 *$ & $(2.23)$ & -.23 & $(-1.10)$ \\
\hline Agric./Craft Occ. & -.08 & $(-.35)$ & -.01 & $(-.05)$ & .35 & (1.68) & -.30 & $(-1.44)$ \\
\hline Low Skill Occ. & .15 & $(.57)$ & -.02 & $(-.14)$ & -.21 & $(-1.25)$ & $-.549 *$ & $(-1.94)$ \\
\hline Urban Resident & $-.16^{*}$ & $(-2.05)$ & -.11 & $(-1.24)$ & $-.16^{*}$ & $(-2.00)$ & -.12 & $(-1.35)$ \\
\hline Children in $\mathrm{HH}$ & $-.15^{*}$ & $(-2.14)$ & -.10 & $(-1.20)$ & .00 & $(.97)$ & -.04 & $(-.44)$ \\
\hline Church Attend. & $.06 * *$ & $(3.24)$ & $.09 * *$ & $(3.37)$ & $.08 * *$ & $(3.30)$ & $.08 *$ & $(2.67)$ \\
\hline Catholic & -.05 & $(-.32)$ & -.07 & $(-.58)$ & .13 & $(1.16)$ & .24 & $(1.49)$ \\
\hline Protestant & .11 & (1.04) & .13 & $(1.00)$ & $.31 *$ & $(2.29)$ & .23 & $(1.76)$ \\
\hline Other religion & -.00 & $(-.02)$ & -.01 & $(-.07)$ & $-.85^{* *}$ & $(-2.65)$ & $-.91 * *$ & $(-4.64)$ \\
\hline Cut1/Constant & 3.39 & $(9.42)$ & 4.20 & $(9.32)$ & -6.32 & $(-13.97)$ & -4.59 & $(-11.78)$ \\
\hline Cut2 & 4.08 & $(1.82)$ & 5.01 & $(9.74)$ & - & - & - & - \\
\hline Cut3 & 5.71 & (15.08) & 6.34 & (11.89) & - & - & - & - \\
\hline $\mathrm{N}$ & \multicolumn{2}{|c|}{10464} & \multicolumn{2}{|c|}{9895} & \multicolumn{2}{|c|}{8498} & \multicolumn{2}{|c|}{8066} \\
\hline $\mathrm{R}^{2}$ & \multicolumn{2}{|c|}{.14} & \multicolumn{2}{|c|}{.12} & \multicolumn{2}{|c|}{.24} & \multicolumn{2}{|c|}{.22} \\
\hline
\end{tabular}

Robust Z-statistics in parentheses

International Survey Program, 2004

Shaded cells indicate coefficients are significantly $(p<.05)$ different between women and men. Logistic tests are based on odds ratios and changes in the predicted probabilities for a given coefficient across all levels of the outcome variable. All models control for country fixed effects

${ }^{a}$ Voting models are missing Flanders and exclude Australia

$* p<.05, * * p<.01$ 
Table 4 OLS regression results for demographic and attitudinal predictors of private, collective, and direct political contact activism among women $(N=10,464)$ and men $(N=9,895)$ across 18 industrialized democracies.

\begin{tabular}{|c|c|c|c|c|c|c|c|c|c|c|c|c|}
\hline \multirow{2}{*}{ Political Attitudes } & \multicolumn{4}{|c|}{ Private Activism } & \multicolumn{4}{|c|}{ Collective Activism } & \multicolumn{4}{|c|}{ Political Contact Activism } \\
\hline & \multicolumn{2}{|c|}{ Women } & \multicolumn{2}{|c|}{$\underline{\text { Men }}$} & \multicolumn{2}{|c|}{ Women } & \multicolumn{2}{|c|}{$\underline{\text { Men }}$} & \multicolumn{2}{|c|}{ Women } & \multicolumn{2}{|c|}{$\underline{\text { Men }}$} \\
\hline Trust in Govt. & $-.04 * *$ & $(.01)$ & $-.03 * *$ & $(.01)$ & $-.03 * *$ & $(.01)$ & -.02 & $(.01)$ & $-.03 * *$ & $(.01)$ & $-.02 * *$ & $(.01)$ \\
\hline Political Efficacy & $.05 * *$ & $(.00)$ & $.03 * *$ & $(.01)$ & $.04 * *$ & $(.00)$ & $.03 * *$ & $(.01)$ & $.03 * *$ & $(.00)$ & $.03 * *$ & $(.00)$ \\
\hline Political Interest & $.23 * *$ & $(.01)$ & $.22 * *$ & $(.01)$ & $.30 * *$ & $(.02)$ & $.31 * *$ & $(.01)$ & $.23 * *$ & $(.02)$ & $.25^{* *}$ & $(.02)$ \\
\hline \multicolumn{13}{|l|}{ Controls } \\
\hline University Deg. & $.22 * *$ & $(.02)$ & $.18^{* *}$ & $(.03)$ & $.15^{* *}$ & (.03) & $.12 * *$ & $(.03)$ & $.15^{* *}$ & $(.02)$ & $.14^{* *}$ & $(.02)$ \\
\hline Age & $.01 *$ & $(.00)$ & $.01 *$ & $(.00)$ & $.01 * *$ & $(.00)$ & $.02 * *$ & $(.00)$ & .01 & $(.00)$ & $.01 * *$ & $(.00)$ \\
\hline Age-squared & $-.00 * *$ & $(.00)$ & $-.00 * *$ & $(.00)$ & $-.00 * *$ & $(.00)$ & $-.00 * *$ & $(.00)$ & $-.00 * *$ & $(.00)$ & $-.00 * *$ & $(.00)$ \\
\hline Married/Widow & $-.11 * *$ & $(.03)$ & .02 & $(.02)$ & $-.15 * *$ & $(.02)$ & -.04 & $(.02)$ & -.02 & $(.02)$ & $-.07 * *$ & $(.02)$ \\
\hline Div./Sep. & -.06 & (.04) & $.06^{*}$ & (.03) & -.06 & $(.03)$ & -.00 & $(.04)$ & $.06 * *$ & $(.02)$ & .00 & $(.02)$ \\
\hline Employed F-T & -.03 & $(.02)$ & .03 & $(.02)$ & -.02 & $(.02)$ & .04 & $(.03)$ & -.00 & $(.02)$ & .01 & $(.02)$ \\
\hline Employed P-T & $.06^{*}$ & $(.03)$ & $.14 * *$ & $(.04)$ & .04 & $(.02)$ & $.13^{*}$ & $(.05)$ & .01 & $(.02)$ & $.12 * *$ & $(.03)$ \\
\hline Spouse Emp. F-T & $.10^{* *}$ & $(.02)$ & $.06 *$ & $(.02)$ & .05 & $(.03)$ & .04 & $(.02)$ & .02 & $(.01)$ & .03 & $(.02)$ \\
\hline Spouse Emp. P-T & $.10^{* *}$ & $(.02)$ & $.09 * *$ & $(.02)$ & .04 & $(.05)$ & .05 & (.03) & .03 & $(.02)$ & $.05^{*}$ & $(.02)$ \\
\hline Professional Occ. & $.23 * *$ & (.04) & .10 & $(.05)$ & .09 & $(.04)$ & $-.13^{*}$ & $(.06)$ & $.06^{*}$ & $(.03)$ & .04 & (.04) \\
\hline Technical Occ. & $.20 * *$ & $(.03)$ & .08 & (.06) & .05 & $(.03)$ & $-.14 *$ & $(.05)$ & .04 & $(.02)$ & -.02 & $(.03)$ \\
\hline Service Occ. & $.09 * *$ & $(.03)$ & -.00 & $(.07)$ & -.03 & $(.03)$ & $-.15 * *$ & $(.05)$ & -.01 & $(.02)$ & -.05 & $(.03)$ \\
\hline Agric./Craft Occ. & -.05 & $(.04)$ & -.13 & $(.06)$ & $-.07 *$ & $(.03)$ & $-.21 * *$ & $(.07)$ & -.06 & $(.03)$ & $-.13 * *$ & $(.04)$ \\
\hline Low Skill Occ. & -.09 & $(.06)$ & $-.14 *$ & $(.07)$ & $-.09 *$ & (.04) & $-.15^{*}$ & $(.05)$ & $-.11^{* *}$ & $(.02)$ & $-.12 *$ & (.04) \\
\hline Urban Resident & -.00 & $(.03)$ & .03 & $(.03)$ & .02 & $(.03)$ & .03 & $(.03)$ & -.02 & $(.03)$ & -.03 & $(.03)$ \\
\hline Children in $\mathrm{HH}$ & -.02 & (.03) & -.01 & $(.01)$ & -.03 & $(.02)$ & -.03 & $(.02)$ & -.00 & $(.02)$ & .01 & $(.02)$ \\
\hline Church Attend. & .01 & $(.01)$ & $.03 * *$ & $(.01)$ & .01 & $(.01)$ & $.03 * *$ & $(.01)$ & .00 & $(.00)$ & $.02 * *$ & $(.01)$ \\
\hline Catholic & $-.19 * *$ & $(.02)$ & $-.17 * *$ & $(.03)$ & $-.18 * *$ & (.03) & $-.14 * *$ & $(.02)$ & $-.06^{* *}$ & $(.02)$ & $-.09 * *$ & $(.02)$ \\
\hline Protestant & $-.07 * *$ & $(.02)$ & -.07 & $(.03)$ & $-.16 * *$ & (.03) & $-.12 * *$ & (.03) & -.03 & $(.02)$ & -.05 & $(.02)$ \\
\hline Other religion & -.09 & $(.05)$ & $-.13 * *$ & $(.04)$ & -.07 & $(.04)$ & $-.09 * *$ & $(.03)$ & .02 & $(.03)$ & -.04 & $(.05)$ \\
\hline Constant & .95 & $(.10)$ & .95 & $(.10)$ & .36 & $(.08)$ & .19 & $(.10)$ & .34 & $(.08)$ & .25 & $(.08)$ \\
\hline $\mathrm{R}^{2}$ & \multicolumn{2}{|c|}{.29} & \multicolumn{2}{|c|}{.24} & \multicolumn{2}{|c|}{.24} & \multicolumn{2}{|c|}{.20} & \multicolumn{2}{|c|}{.22} & \multicolumn{2}{|c|}{.22} \\
\hline
\end{tabular}

Robust standard errors in parentheses

International Survey Program, 2004

Shaded cells indicate coefficients are significantly different between women and men $(p<.05)$ using Chow tests. All models control for country fixed effects

$* p<.05, * * p<.01$

for women. What remains unclear is whether being employed part-time enabled men to exercise their desire to be politically involved or whether politically involved men are more likely to choose part-time employment. Contrary to our expectations and our analysis on voting, full-time employment is not significantly related to any type of activism, for women nor for men. Yet, for private and collective activism the link between full-time employment and participation is significantly weaker among women than men, suggesting that for women, employment is not as strong a path to activism as it is to men, and that it is for women's voting behavior (see Table 3). Looking at the effect of occupational status, our results confirm Hypothesis 6: women's employment in professional and technical occupations has a stronger positive link to both private and collective activism. In the first case, women's move- ment into more powerful jobs may thus widen women's advantage, and in the second case, may help ameliorate men's advantage.

Finally we find in line with Hypothesis 7 and recent U.S. research for attendees of Black churches (Robnett and Bany 2009) and mosques (Read 2007), that men who attend church more often receive a consistent participation boost, church attendance has no effect on women's activism. We also explored the possibility that religious attendance would matter particularly for housewives, as a link to the public arena. We found that housewives who attend church more often are more likely than similar housewives to participate in private and collective activism, but not direct contact activism. Looking at different religious affiliations, we find few differences. Compared to men and women with no religious denomination, both Catholic men and women are 
less politically engaged. Male members of an "other" religion are much less likely to participate in private and collective action than non-affiliated men, though among women such a divide is not apparent. Among women, Protestants are significantly less involved in individual action, while there is no significant effect among males.

\section{Discussion}

Rather than an overall gender gap in political participation, our results suggest a variety of gender gaps across modes of participation. Indeed, substantively disaggregated measures of political behavior reveal that political engagement is not just a matter of more or less, but rather of men and women engaging differently. While feminist research on women's political participation has long called attention to this process (Bourque and Grossholtz 1998; Harrison and Munn 2007; Sarvasy and Siim 1994; Siim 2000), few empirical studies have tested and demonstrated such effects, especially in a cross-national sample. In fact, our approach reveals one domain where women are significantly more active than men: private activism. Women, on average, are more likely to sign petitions, boycott/buy products for political reasons, and donate to or raise money for social and political groups. This holds even controlling for main socio-economic and attitudinal differences. Notably, these private/individualistic actions are the least resource dependent and most easily incorporated in daily life.

Initially it seemed that men and women did not differ in their electoral behavior. However, once controlling for attitudinal characteristics, women are more likely to vote than men. Thus, if women were to develop an interest in politics and feelings of political efficacy equal to that of men, women would vote more than men. As prior work has shown, women and men's views about women's political participation are subject to public portrayals (Schwarz et al. 1987), suggesting it is not unlikely that attitudes may shift and ultimately impact political involvement. Indeed several studies have shown the importance of developing an awareness of social and political problems as a spur to greater involvement (Bernstein 2005; Schreiber 2002; Stake 2007).

Nevertheless, there are three aspects of participation where men are more involved: political party membership, collective activism and political contact. Even though the gender gap often decreases significantly after controlling for attitudinal characteristics (for collective activism and political contact), it appears that men are more likely than women to become a party member, to take part in a demonstration and attend political meetings, or engage in political contact. Active engagement with a political party is not something most respondents report doing, but especially not women. Such participation puts high demands on resources including time and money. In comparison to sending in a check, joining a demonstration or attending a political meeting takes time and planning, and women who are balancing higher family responsibilities, along with work, friends, and non-political engagements may be less inclined to contact politicians.

In explaining the gender gap, many of our results mirrored findings of those based on a narrower U.S. sample. In and of itself, this finding suggests intriguing similarities in the process shaping gender inequality across Western democracies, and is an important step forward in research on participation. However, from the perspective of gender, these approaches may nevertheless fall short. Specifically, we found that typical economic and familial resource arguments are best at explaining institutional forms of participation: voting and party membership. Along these lines prior work in the U.S. has demonstrated that husbands' greater political involvement benefits disproportionately from having control over finances and small amounts of time (Burns et al. 1997). In contrast, when it comes to the three activism measures, economic and familial resources and experiences do not always matter as expected. Private activism is often boosted by economic ties perhaps because it is easier to incorporate such action by those with the busiest lives: working, with family responsibilities and in dual-earner couples. Though being employed full-time does not increase involvement. Collective activism is highly dependent on time availability. Women who are married, employed in "bad" jobs, and committed to particular denominations may opt out of such commitments, and their level of employment is much more weakly related to participation than it is for men. However, men with stronger ties to the economic also experience less involvement, which suggests time - not money - may be the main differentiating factor. Finally, fewer factors differentiate political contact among each gender. Family characteristics behave counter to theory, such that married men are less involved and divorced or separated women are more involved in such action. Women in low skill occupations are highly unlikely to engage in contact, while professional women are highly likely to. The same gap was not apparent among men. Thus, to the extent that women participate in contact forms of activism less, socialization may be particularly pernicious, with women less interested in forwarding personal opinions to a wider audience in newspapers, on the internet or to political officials (Fox and Lawless 2004). Experiences that counter traditional expectations, such as education, professional employment, and leaving a marriage may enable women to counter such built-in pressures (Bolzendahl and Myers 2004). Only by including these more female-dominated and less institutional forms of participation are the gender limitations of economic and familial resource explanations clarified. 
Overall, our findings modify earlier claims of a gender gap in political participation, but also raise a variety of questions and new directions for research on political participation. Controlling for a variety of relevant demographic characteristics and political attitudes did not impact gender gaps as much as might be expected based on theories of differential resources or gender role socialization. Given that women are often discouraged from public and/or leadership roles, we expected this to greatly undermine gender differences. However including these attitudes only weakened some gender differences in political participation. Our reliance on prior theory and research in this area cannot fully speak to these variations in gender differences or uncover the relative importance of mechanisms based on personal interest, life experiences, or institutional constraints. While we have pulled from a variety of quantitative and qualitative work in contextualizing our findings, as well as rigorous methods to explore the questions raised, further research with more finegrained measures and a longitudinal component would be helpful. As more women take highly visible political roles, as has been the trend in recent years, women's political efficacy and interest will catch up to men's and this relationship may strengthen and increase women's participation (Atkeson 2003; Atkeson and Rapoport 2003; Fox and Lawless 2004). Examining these relationships over a longer period of time would help address such questions. Future research may also do more to disentangle political activism into a meaningful substantive typology of actions. For example, in a Belgian study on demonstrations, van Aelst and Walgrave (2001) reveal that gender of demonstrators depends strongly on the protest issue. Research is increasingly acknowledging the importance of noninstitutional forms of political activism as being legitimate and powerful influences on (formal) political outcomes (Dalton 2008; Pattie et al. 2003), but more work must be done to develop the theoretical underpinnings of these different forms of action, their stratification among population groups, and impact on the political process.

Along these lines, more research is needed to investigate the implications of gender gaps in participation for political outcomes and gender equality more generally. On one hand, if women engage in more individual, private actions, but politicians pay more attention to the collective, public actions men are more likely to engage in, policy decisions might reflect men's demands more than women's. On the other hand, if women increase their political interest and efficacy over time, female voters may dominate ballots in the future. Future research may also open the way for further hypothesis testing on the differential effect of different characteristics on participation among men and women. Finally, the cross-national results provide a strong background with which to study national context in greater detail. While our focus was looking beyond country characteristics, it must be recognized that political participation typically occurs in a national context. Hence, further investigations on the influence of political and cultural characteristics are needed.

Acknowledgements This research was financially supported by the University of California and Utrecht University Collaborative Grant Program and the UCI Center for the Study of Democracy. We thank Russell Dalton and members of the UCI Population, Society and Inequality colloquium for helpful on comments on earlier drafts, as well as Vincent Buskens and Shawna Smith for methodological comments.

Open Access This article is distributed under the terms of the Creative Commons Attribution Noncommercial License which permits any noncommercial use, distribution, and reproduction in any medium, provided the original author(s) and source are credited.

\section{References}

Abbott, A. (1993). The sociology of work and occupations. Annual Review of Sociology, 19, 187-209.

Abramson, P. (1983). Political attitudes in America. San Francisco: Freeman.

Allison, P. D. (1999). Comparing logit and probit coefficients across groups. Sociological Methods and Research, 28, 186-208.

Allison, P. D. (2002). Missing data. Thousand Oaks: Sage Publications.

Alwin, D. F., Cohen, R. L., \& Newcomb, T. M. (1991). Political attitudes over the life span: The Bennington women after 50 years. Madison: Wisconsin University Press.

Armingeon, K. (2007). Political participation and associational involvement. In J. van Deth, J. R. Montero, \& A. Westholm (Eds.), Citizenship and involvement in European democracies: A comparative analysis (pp. 358-383). London: Routledge.

Atkeson, L. R. (2003). Not all cues are created equal: the conditional impact of female candidates on political engagement. The Journal of Politics, 65, 1040-1061.

Atkeson, L. R., \& Rapoport, R. B. (2003). The more things change the more they stay the same: examining differences in political communication, 1952-2000. Public Opinion Quarterly, 67, 495521.

Banducci, S. A., Donovan, T., \& Karp, J. A. (1999). Minority representation, empowerment and participation. Journal of Politics, 66, 534-556.

Batalova, J., \& Cohen, P. N. (2002). Premarital cohabitation and housework: couples in cross-national perspective. Journal of Marriage and the Family, 64, 743-755.

Bernstein, A. G. (2005). Gendered characteristics of political engagement in college students. Sex Roles, 52, 299-310.

Bolzendahl, C., \& Brooks, C. (2007). Women's political representation and welfare state spending in twelve capitalist democracies. Social Forces, 85, 1509-1534.

Bolzendahl, C., \& Myers, D. J. (2004). Feminist attitudes and support for gender equality: opinion change in women and men, 1974 1998. Social Forces, 82, 762-789.

Bourque, S., \& Grossholtz, J. (1998). Politics an unnatural practice: Political science looks at female participation. In A. Phillips (Ed.), Feminism and politics (pp. 23-43). Oxford: Oxford University Press.

Brownmiller, S. (1984). Femininity. New York: Simon \& Schuster. 
Burns, N. (2007). Gender in the aggregate, gender in the individual, gender and political action. Politics \& Gender, 3, 104-124.

Burns, N., Schlozman, K. L., \& Verba, S. (1997). The public consequences of private inequality: family life and citizen participation. American Political Science Review, 91, 373389.

Carroll, S. J. (Ed.). (2001). The impact of women in public office. Bloomington: Indiana University Press.

Chanley, V. A., Rudolph, T. J., \& Rahn, W. M. (2000). The origins and consequences of public trust in government: a time series analysis. Public Opinion Quarterly, 64, 239-256.

Dalton, R. J. (2006). The two faces of citizenship. Democracy \& Society, 3, 21-29.

Dalton, R. J. (2008). Citizenship norms and the expansion of political participation. Political Studies, 56, 76-98.

Dalton, R. J., Scarrow, S. E., \& Cain, B. E. (2003). Democracy transformed?: Expanding political opportunities in advanced industrial democracies. Irvine: Center for the Study of Democracy: University of California.

Dyck, J. J., \& Lascher, E. L., Jr. (2009). Direct democracy and political efficacy reconsidered. Political Behavior, 31, 401-427.

Fox, R. L., \& Lawless, J. L. (2004). Entering the arena? Gender and the decision to run for office. American Journal of Political Science, 48, 264-280.

Fridkin, K., \& Kenney, P. (2007). Examining the gender gap in children's attitudes toward politics. Sex Roles, 56, 133-140.

Gabriel, O. W., \& van Deth, J. W. (1995). Political interest. In J. W. van Deth \& E. Scarbrough (Eds.), The impact of values (pp. 390411). Oxford: Oxford University Press.

Gallego, A. (2007). Inequality in political participation: Contemporary patterns in European countries. Irvine: Center for the Study of Democracy: University of California.

Githens, M., Norris, P., \& Lovenduski, J. (1994). Different roles, different voices: Women and politics in the United States and Europe. New York: Harper Collins College Publishers.

Goss, K. (2003). Rethinking the political participation paradigm: the case of women and gun control. Women and Politics, 25, 83-118.

Gupta, S. (1999). The effects of transitions in marital status transitions on men's performance of housework. Journal of Marriage and Family, 61, 700-711.

Hadjar, A., \& Schlapbach, F. (2009). Educational expansion and interest in politics in temporal and cross-cultural perspective: a comparison of West Germany and Switzerland. European Sociological Review, 25, 271-286.

Harrison, L., \& Munn, J. (2007). Gendered (non)participants? What constructions of citizenship tell us about democratic governance in the twenty-first century. Parliamentary Affairs, 60, 426-436.

Hooghe, M., \& Stolle, D. (2004). Good girls go to the polling booth, bad boys go everywhere: gender differences in anticipated political participation among American fourteen-year-olds. Women \& Politics, 26, 1-23.

Inglehart, R. (1997). Modernization and postmodernization: Cultural, economic, and political change in 43 societies. Princeton: Princeton University Press.

Inglehart, R., \& Norris, P. (2003). Rising tide: Gender equality and culture change around the world. Cambridge: Cambridge University Press.

ISSP (2004). Citizenship, ZA No. 3950. Retrieved from http://www. gesis.org/en/services/data/survey-data/issp/modules-study-overview/citizenship/.

Janoski, T. (1998). Citizenship and civil society: A framework of rights and obligations in liberal, traditional, and social democratic regimes. Cambridge: Cambridge University Press.

Knudsen, K., \& Waerness, K. (2008). National context and spouses' housework in 34 countries. European Sociological Review, 24, 97-113.
Lister, R. (1998). Citizenship and difference: Towards a differentiated universalism. European Journal of Social Theory, 1, 7190.

Lister, R. (2003). Citizenship: Feminist perspectives. New York: Palgrave Macmillan.

Lister, R. (2007). Inclusive citizenship: realizing the potential. Citizenship Studies, 11, 49-61.

Lister, R., Williams, F., Anttonen, A., Bussemaker, J., Gerhard, U., Heinen, J., et al. (2007). Gendering citizenship in Western Europe: New challenges for citizenship research. Bristol: Policy.

Long, J. S. (1997). Regression models for categorical and limited dependent variables. Thousand Oaks: Sage Publications.

Long, J. S. (2007). Comparing group effects in nonlinear models: Statistical problems and substantive insights. Retrieved from http://www.indiana.edu/ jslsoc/files_research/rm4cldv/group compare/long_group_nd_2007-04-16.pdf.

Long, J. S., \& Freese, J. (2006). Regression models for categorical dependent variables using stata (2nd ed.). College Station: Stata.

Lovenduski, J. (1998). Gendering research in political science. Annual Review of Political Science, 1, 333-356.

Lovenduski, J. (2005). Feminizing politics. Cambridge: Polity.

Martin, P. Y. (2004). Gender as social institution. Social Forces, 82, $1249-1273$.

Norris, P. (2002). Democratic phoenix: Reinventing political activism. Cambridge: Cambridge University Press.

Norris, P., \& Curtis, J. (2006). If you build a political web site, will they come? The internet and political activism in Britain. International Journal of Electronic Government Reserach, 2, 121.

Orloff, A. S. (1996). Gender in the welfare state. Annual Review of Sociology, 22, 51-78.

Parry, G., Moyser, G., \& Day, N. (1992). Political participation and democracy in Britain. Cambridge: Cabridge University Press.

Pattie, C., Seyd, P., \& Whiteley, P. (2003). Citizenship and civic engagement: attitudes and behaviour in Britain. Political Studies, $51,443-468$.

Paxton, P., Kunovich, S., \& Hughes, M. M. (2007). Gender in politics. Annual Review of Sociology, 33, 263-284.

Poortman, A.-R. (2000). Sex differences in the economic consequences of separation: a panel study of the Netherlands. European Sociological Review, 16, 367-383.

Putnam, R. D. (2000). Bowling alone: The collapse and revival of american community. New York: Simon \& Schuster.

Rapoport, R. B. (1981). The sex gap in political persuading: where the 'structuring principle' works. American Journal of Political Science, 25, 32-48.

Read, J. G. (2007). More of a bridge than a gap: Gender differences in Arab-American political engagement. Social Science Quarterly, $88,1072-1091$.

Risman, B. (1998). Gender vertigo. New Haven: Yale University Press.

Robnett, B., \& Bany, J. (2009). Church participation and the persistence of a political participation gender gap among African Americans. Unpublished manuscript.

Rotolo, T. (2000). A time to join, a time to quit: the influence of life cycle transitions on voluntary association membership. Social Forces, 78, 1133-1161.

Sarvasy, W., \& Siim, B. (1994). Gender, transitions to democracy, and citizenship. Social Politics, 1, 249-255.

Sayer, L. (2005). Gender, time, and inequality: Trends in women's and men's paid work, unpaid work, and free time. Social Forces, 84, 285-303.

Schlozman, K. L., Burns, N., \& Verba, S. (1994). Gender and the pathways to participation: the role of resources. The Journal of Politics, 56, 963-990. 
Schlozman, K. L., Burns, N., Verba, S., \& Donahue, J. (1995). Gender and citizen participation: is there a different voice? American Journal of Political Science, 39, 267-293.

Schlozman, K. L., Burns, N., \& Verba, S. (1999). "What happened at work today?": A multistage model of gender, employment, and political participation. The Journal of Politics, 61, 29-53.

Scholz, E., Harkness, J., \& Faaß, T. (2008). Issp study monitoring report 2004: GESIS-Methodenberichte.

Schreiber, R. (2002). Injecting a woman's voice: conservative women's organizations, gender consciousness, and the expression of women's policy preferences. Sex Roles, 47, 331-342.

Schwarz, N., Wagner, D., Bannert, M., \& Mathes, L. (1987). Cognitive accessibility of sex role concepts and attitudes toward political participation: the impact of sexist advertisements. Sex Roles, 17, 593-601.

Schwindt-Bayer, L. A. (2006). Still supermadres? Gender and the policy priorities of latin American legislators. American Journal of Political Science, 50, 570-585.

Siim, B. (2000). Gender and citizenship: Politics and agency in France, Britain and Denmark. Cambridge: Cambridge University Press.

Stake, J. (2007). Predictors of change in feminist activism through women's and gender studies. Sex Roles, 57, 43-54.

Stolle, D., Hooghe, M., \& Micheletti, M. (2005). Politics in the supermarket: political consumerism as a form of political participation. International Political Science Review, 26, 245-269.
Ulbig, S. G. (2002). Policies, procedures, and people: sources of support for government? Social Science Quarterly, 83, 789-809.

van Aelst, P., \& Walgrave, S. (2001). Who is that (wo)man in the street? From normalization of protest to the normalization of the protestor. European Journal of Political Research, 39, 461-486.

Verba, S. (1996). The citizen as respondent: sample surveys and American democracy presidential address, American Political Science Association, 1995. The American Political Science Review, 90, 1-7.

Verba, S., Nie, N., \& Kim, J.-O. (1978). Participation and political equality: A seven-nation comparison. Cambridge: Cambridge University Press.

Verba, S., Burns, N., \& Schlozman, K. L. (1997). Knowing and caring about politics: gender and political engagement. The Journal of Politics, 59, 1051-1072.

Verba, S., Schlozman, K. L., \& Brady, H. E. (1995). Voice and equality: Civic voluntarism in American politics. Campbridge, MA: Harvard University Press.

Waring, M., Greenwood, G., \& Pintat, C. (2000). Politics: Women's insight. Cambridge, MA: Harvard University Press.

Wattenberg, M. (2002). Where have all the voters gone? Cambridge: Harvard University Press.

West, C., \& Zimmerman, D. H. (1987). Doing gender. Gender \& Society, 1, 125-151.

Young, I. M. (2004). Situated knowledge and democratic discussions. In J. Anderson \& B. Siim (Eds.), The politics of inclusion and empowerment (pp. 19-35). New York: Palgrave Macmillan. 